\title{
Domestic Violence
}

\author{
Nasreen Aslam Shah \\ \& \\ Syed Faisal Hashmi \\ Women's Studies \\ University of Karachi
}

\begin{abstract}
Domestic violence is prevailing all over the world rapidly. In Mexico City for example, one in three women report violence from the spouse or partner .Another study shows that one out of every five Colombian women were beaten by the partner. . Domestic violence has not only one dimension but it has many types like marital rape, stalking, harassing, honor killings etc which existed in almost all countries in different forms of violence. The increasing ratio of violence also demonstrates that male still think women their subordinate. The major reasons behind increasing violence are imbalances in society and inequalities in gender relationships. The methodology used in the research based on content analysis of news on domestic violence against women from their male partners/spouses published in newspapers.

$$
\begin{aligned}
& \text { تلخيص المقال }
\end{aligned}
$$

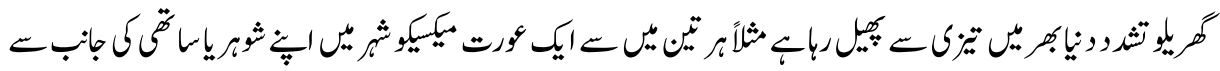

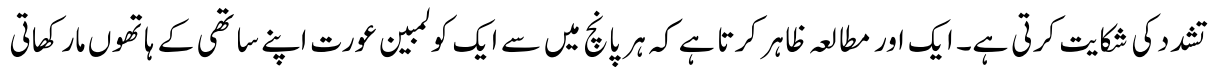

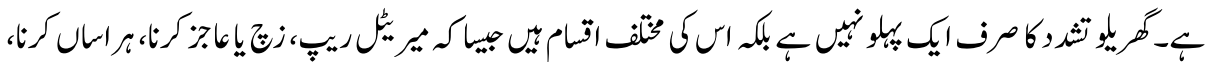

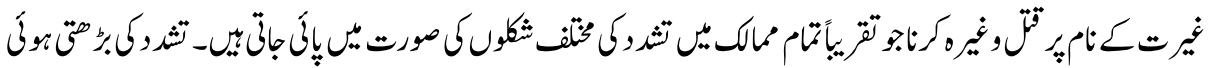

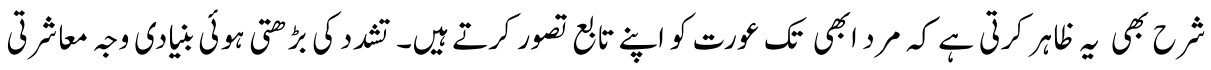

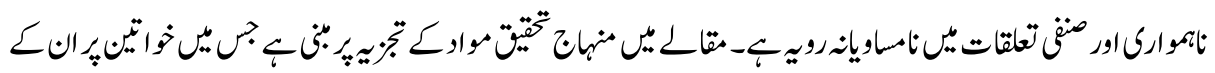

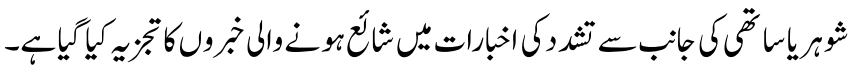

"No nation can rise to the height of glory unless your women are side by side with you. We are victims of evil customs. It is a crime against humanity that our women are shut up within the four walls of the houses as prisoners. There is no sanction any where for the deplorable condition in which our women have to live." Quaid-e-Azam Muhammad Ali Jinnah (Speech at a meeting of the Muslim University Union, Aligarh March 10, 1944).

Over the past centuries women through the world have been subservient to the male giving rise to a "Patriarchal Society". Even today in the $21^{\text {st }}$ century a child's lineage in male. The women being considered only as the vessel in which the child is conceived. 
Subsequently, after giving birth she is responsible to succor, nurture and raise it, the means to do so being provided by the male there by making the woman dependent on the male to treat, use and dispose off as his whims or likes dictates. (Hayat.A.A:2002)

Women is the sufferer in the hands of men all over the world. Perhaps women were free and equal in quite very old times. Gradually, the women were treated as inferior and moreover, they treated themselves inferior. The lack of physical power leads to general timidity in women. During the middle ages, cruel and inhuman treatment was meted out to them. They followed the Holy Scripture in which they were told to get, happiness by submissiveness. The women sacrificed every thing including their lives. The higher the sacrifice, the higher the salvation became a motto for women. In reality women rarely had an identity apart from that given to them as wives, mothers, and daughters. Although, they were worshipped as deities at home, they were treated as second class members of the family. (Bahl, Manish:2007).

The Decade for women which began with the International Women's Year Conference in Mexico city in 1975 ended with the Nairobi World Conference in 1985 to review and appraise the achievements of women with its main themes ,'Equality, Development and Peace", marked an era of ever increasing developed consciousness among both women and men. The world is now engrossed in more discussions of women's problems, more advocacy of their rights (Akanda, Latifa\& Shamim, Ishrat :1985).Afterwards during the Fourth World Conference held in Beijing,China from 4-15 September 1995, twelve key areas were selected for work and violence against women was one of them. ${ }^{1}$ After five years, during the UN Millennium Summit in September 2000, promotion of gender equality and empowerment of women was included in the eight Millennium Development Goals to be achieved by 2015 .These Millennium Development Goals were drawn from the actions and targets contained in the Millennium Declaration that was adopted by 189 nations and signed by 147 Heads of state and Governments. But despite all these initiatives to end violence against women the interesting and terrible fact is that, only 44 countries out of 193 made laws against domestic violence.

The table below shows an overview of about the degree of violence between different countries.

Table

Societies with Wife Abuse World wide

\begin{tabular}{|l|c|}
\hline Country & Proportion of Women \\
\hline Developed regions & 25 \\
\hline Belgium & 25 \\
\hline Canada & $59 a$ \\
\hline Japan & 21 \\
\hline NetherLands & \\
\hline
\end{tabular}




\begin{tabular}{|l|c|}
\hline New Zealand & 17 \\
\hline Norway,Trondheim & 25 \\
\hline United States & 28 \\
\hline Africa & 42 \\
\hline Kenya, Kissi District & $40 \mathrm{~b}$ \\
\hline Zambia & 46 \\
\hline Uganda, Kampala & 60 \\
\hline United Republic of Tanzania,Dar es Salaam and 3 districts & 30 \\
\hline Latin America and the Carribean & 30 \\
\hline Antigua & 26 \\
\hline Barbados & $54 \mathrm{c}$ \\
\hline Chile, Santiago & 20 \\
\hline Costa Rica & 60 \\
\hline Colombia & 36 \\
\hline Ecuador,Quito & 34 \\
\hline Guatemala & $57 \mathrm{~d}$ \\
\hline Mexico, Mexico City & $44 \mathrm{~d}$ \\
\hline Jalisco State,urban & 35 \\
\hline Jalisco State,urban Suriname & \\
\hline Asia and the Pacific & 22 \\
\hline India, southern Karnataka(3 villages) & \\
\hline Jullundur District, Punjab(1village) Higher caste & 75 \\
\hline Scheduled lower caste & 22 \\
\hline Higher caste & 38 \\
\hline Korea, Republic of Malaysia & 39 \\
\hline Papua New Guinea, urban & 58 \\
\hline Papua New Guinea, & 67 \\
\hline rural (19 villages) & 60 \\
\hline Sri Lanka, Colombo & \\
\hline
\end{tabular}

Note. Based on survey results on percentage of adult women who have been physically assaulted by an intimate partner compiled and published in the United Nations Report on the status of Women, 1995; New York: Author.

Based on a limited (17\%) on questionnaires distributed nationally, through women's group, adult education classes and the media.

a Based on a sample of women from shanty compounds.

6 Based on a sample of women attending child welfare clinics.

cWomen on "DIF" (social welfare) register

dPercentage beaten within the last year (Encyclopedia of Violence peace $\mathcal{L}$ Conflict: Volume- 2 F-PE pg 4)

Violence against women has traditionally occupied a central place in our culture. It is a world wide phenomenon which takes many forms and occurs across national, cultural and social borders (Hayat.A.A:2002). Domestic violence is the umbrella term used to describe physical or mentally abusive behavior between family members. Family members, for the purpose of defining domestic violence, are those persons who reside in a family -like setting or are involved in an intimate relationship (Boyles, William \& 
Myres Sara: 1990). Another definition explains domestic violence as "Violence perpetrated by intimates against intimates and exists as a powerful tool of oppression" (Hayat.A.A.2002).

The nature and the factors responsible for commitment of violence are under going changes with the changing socio-economic structure (Akanda, Latifa\& Shamim: Ishrat 1985).Many people wrongly believe that domestic violence involves only physical abuse, whereas it can take many forms and usually revolves round the attempt to control the partner. It can take the following forms:

The most heinous method is by burning. Other types are:-Beating, custodial abuse and torture, mutilation, disfiguring the face/ body or killing with acid, rape, sodomy (carnal intercourse against nature) Incest, spousal murder, burning.

Such as the husband consistently criticizes the wife. Violence against women is also committed by putting the women in isolation. The husband controls the wife and watches as to what she does and where she goes. The husband often locks her inside the house. Moreover, sexual abuse is also committed by the husband.

When the husband forces the wife to engage in sexual acts repugnant to her or has sex forcibly against her will, resulting in marital rape. At times expects the wife to be "nice socially", with his bosses and colleagues to get economic advantages. An indirect form of prostitution. Other forms include intimidation, threat of separation and guilt regarding the children's upbringing, financial stringency, ill treatment by in-laws, who expect all the house labour e.g. cooking, washing, cleaning etc must be done by the daughter -in- law. Besides many other forms of mental cruelty are practiced like segregation from the family's decision- making, no say in family's future prospects and above all being treated simply as a domestic menial sexual slave.

One of the most torturous forms of domestic abuse is to burn the victim and depict it as an accident .The modus operandi is to engineer a stove burst or contrive that clothes worn of nylon or other inflammable material caught fire. The average age limit of such victims 22 to 30 years. Statistics show that this is one of the most common frequently method used by family members to get rid of women whose death would benefit them materially or salvage their so called honor and ego. It can involve wives, daughters -in- laws, sistersin-laws and even daughters. This indeed, is a gruesome crime against all tenets of morality and humanity.

The main motives are: Greed, demand of dowry or money from the in-laws, desire to remarry, which is resented opposed by the first wife, who as such becomes a target, the man being involved with another woman1. Monetary reasons, jealousy and suspicion, instigation by in-laws, house work, Impact of alcohol economic independence of wife or wife's high self- esteem ( she thinks too much of herself)dispute over children. ${ }^{2}$ These all 
are existed in all over the globe on different levels according to circumstances and culture ,but their results effects negatively on women status.

Development changes women's status economically in many developed countries. It also influences their personal lives, family relations, reproductive roles. However, due to many reasons percentage of domestic abuse increases day by day. In developing or under- developed nations, the situation is even worst. Domestic violence occurs across the world, in various cultures, and affects people across society, irrespective of economic status. In the United States, according to the Bureau of Justice Statistics women are about six times as likely as men to experience intimate partner violence. Percent of women surveyed (national surveys) who were ever physically assaulted by an intimate partner: Barbados (30\%), Canada (29\%), Egypt (34\%), New Zealand (35\%), Switzerland (21\%), and United States (22\%). Some surveys in specific places report figures as high as 50$70 \%$ of women surveyed who were ever physically assaulted by an intimate partner include others, including surveys in the Philippines and Paraguay, report figures as low as $10 \%)^{3}$

The patriarchal system dominates public and private sphere and the males think that it is their right to beat or humiliate woman. Often in the eastern societies, cultural values and false religious interpretations are used to take advantage. Commonly these are gender stereotypes that constitute the concepts and ideologies to see women as vulnerable, brainless and unable to make decisions group. Another factor which increases the ratio of domestic violence in the third world is poverty linked frustration. Due to unstable economic conditions males get frustrated and depressed which make them short tempered. The males usually let their anger out on their wives and feel relaxed.

Women are helpless in these circumstances and forced to tolerate this brutal behavior and action because of the so called social and cultural values and norms. Another cause of women tolerance is their dependency on men. Usually a middle class woman is dependent on his male partner economically. Often she herself creates a sense of dependency. She cannot even make decisions in ordinary matters of her family. Lack of education and poor job opportunities force the middle class women to remain married to men who constantly batter them. This, along with the burden of child care and parental responsibility, forces women to remain in violent homes. Knowing this, men continue abusing their wives with relative impunity. They can be relatively confident that she will not leave him because:(i) She is not economically independent;(ii) She has no place to go to and; (iii) She has the burden of bringing up the children because the society feels that child care is exclusively a mother's job and women who leave children behind become social outcaste (Hayat.A.A.2002).

Pakistan is facing the same problem of increasing domestic violence in its society. Women from lower middle, middle or even elite class are victims of different types and 
levels of violence. Educated or uneducated, dependent or independent they are used to tolerate men's violence. The Pakistani society is a traditional patriarchal society where the male ranges supremacy over female. Our culture, norms, traditions, different misinterpretations of Quran and Ahadith, influences of other cultures create mythologies about women's lower status. Although Article 25 of the Pakistan's Constitution guarantees that there shall be no discrimination on the basis of sex alone and that the State shall make provisions for the protection of women;. Wife battering, marital rape, sexual abuses, physical and mental violence are increasing day by day in our society. These are the shadowed topics which usually do not come under discussion openly because of our traditional concept of losing respect in family or society. The women usually hide this so called personal matter for the protection of his husband's respect instead of taking necessary legal actions.

Domestic violence is often taken as one of male's rights and not to be taken notice of. It is a part of daily routine. Dobash and Dobash use the concept of patriarchy to explain this. This consists of two elements : the structural, that is social structures which delineate women's subordinate role in society, and the ideological, that is the socialization process that ensures acceptance of this.Buzawa and Buzawa sum up the tenets of this theory of :as under:

Women in this model have historically been seen as chattel, unable to manage their own affairs with out the strong leadership of an unauthoritarian family patriarch. The patriarch, in turn, traditionally had the right to enforce male standards of accepted 'feminine' behaviour through whatever means necessary, including force. (Lockton, Deborah: 1997)

If we analyze the situation of women through the violence as reported in renowned newspapers of Pakistan, numerous inhuman and brutal acts would come into sight against the "Khushhal Pakistan" image. Some of these are briefly enumerated below

The Burn cases from stove and acid, murder, mutilation are printed and published in daily newspapers but how many convicted got punishment for that? It still remains a question. As reported during the first eight months of 20081893 women became victims of domestic violence. Among these, 105 women were forced to get married without their consent, 636 women were murdered, 795 were tortured and 65 burn cases were reported. ${ }^{4}$ These cases show the actual male dominating thought of considering and using women as shoe mat or "Pair Ki Juti". The bitter behavior of male siblings does not stop here. For the sake of property or in the name of "Ghairat", the women are hounded and often killed. Karo Kari, Vani and Sawara cases are common and prevailing and such tragedies are taking place almost every day in one part of Pakistan or the other. 
According to a seminar organized by Police in collaboration with the Ministry of Justice and Law in Punjab alone 1797 cases of Karo Kari were registered from 1997 to 30th May 2003. Court gave decision on 1142 cases. The percentage of punishment to the accused was $28 \%$ and $71.97 \%$ were released. During the same time period, 910 cases were registered in Sindh and percentage of punishment was $8.53 \%$ and those held not guilty were $91.4 \%, 57$ cases were registered in Balochistan,39 cases were decided and percentage of accused was 33.3 and 43.13 were held not guilty. In 239 cases of N.W.F.P, 141 were decided by the court and only 7\% were punished and $92.9 \%$ released. According to the seminar $56 \%$ of accused were husbands of murdered women, $2.7 \%$ were father, $8.77 \%$ were brother, $1.7 \%$ sons and 29.42 were other relatives. ${ }^{5}$

These facts and figures are far fewer from the actual figure. As mentioned before, many women do not lodge complaint against their male partners because of social fear, in our society, women are brought up since their childhood and forced to obey whatever is said and to tolerate whatever is done to them. In the name of religion and tradition, women are easily blackmailed. The Government institutions and Non Governmental organizations receive millions of foreign aid every year in the name of poor and helpless women, but a radical change in the attitude is not visible and serious actions for domestic violence are rarely taken. According to the social experts, major causes of diminishing status of women is their vulnerable economic condition, unawareness of legal rights , un Islamic norms , tribal and feudal culture and existence of discriminatory laws. These problems and social conditions create an ambiguous and complicated situation for women for whom it is impossible to come out without any support. Though women in Pakistan are moving towards development through education and increasing employment opportunities, but we still have to look for answer to the question "why the women continue to be victim of domestic violence?" Though they get $33 \%$ representation in provincial and national assemblies, the process of law and policy making for the protection of women is still slow due to the unwillingness of political leaders.

The representatives of masses in assemblies belong to the specific class of feudal and industrialists and they also support the patriarchal values dominating the mainstream society . So how can one expect that they would think about women beyond their specific ideology?

Another aspect of this problem is ineffective law enforcement by the Estate institutions. Many women, who were victim of domestic violence tried to register complaint against their husbands and in- laws, but due to the unsupportive behavior of police, they had to back out. Moreover, in many cases of domestic violence, the accused get protection and support of police, and police threaten the siblings of victimized women.

According to LHRLA and UNICEF collaborated report released in February 2003, "In year 2002 more than 3000 women faced physical violence, in which 1375 women were 
murdered in the name of Karo Kari and 1535 women were injured". The report further reveals that 319 cases of KaroKari were registered in Punjab, 423 in Sindh, 36 in Balochistan and 45 women were killed in N.W.F.P 5. These are those cases which were registered and had become known. ${ }^{6}$

The Islamic Republic of Pakistan was established in the name of Islam to bring relief and give proper rights to all its citizens with out any exception and prejudice against sex, color or race. Women are $49 \%$ of Pakistan's population and they keep struggling for their survival since 1947. No doubt many programmes, planning and strategies were introduced and carried through to better the public sphere of women, but our policy makers ignored the private sphere of women's lives which seriously need reformation of laws and their quicker and effective implementation.

In a major move against domestic violence against women and children, the National Assembly of Pakistan passed a private bill on Tuesday August $4^{\text {th }} 2009$ to prevent the prevalent curse. The bill has comprehensive 28 clauses. According to the bill, domestic violence includes but is not limited to "all intentional acts of gender- based or other physical or psychological abuse committed by an accused against women, children or other vulnerable persons, with whom the accused person is or has been in a domestic relationship". Some of such acts could be "assault" as defined in the Pakistan Penal Code , use of criminal force, criminal intimidation, economic abuse, entry into an aggrieved person's residence without his or her consent , harassment, " mischief" against property, physical abuse , stalking, sexual abuse, verbal and emotional abuse, insults or ridicule, "willful or negligent abandonment of the aggrieved person", wrongful confinement and "other repressive or abusive behaviour ... where such a conduct harms or may cause imminent danger or harm to the safety, health or well being of the aggrieved person". The bill gives an aggrieved person the right to approach a first class magistrate's court and the court must give a decision with in 30 days. The court must prohibit the accused one to from committing or aiding or abetting domestic violence. The first breach of a protection order will be punishable with imprisonment of up to one year, but not less than six months, and a minimum fine of Rs. $100,000 .^{7}$

This surely provides protection to women victimized of domestic violence, but it is also necessary to create awareness among masses about their rights so they can defend themselves from harms and mischief from their male partners.

\section{Methodology}

To analyze the situation of domestic violence, a research was conducted and the coverage of daily Jang, Karachi on domestic violence during 2007 was studied to know about its intensity and impact on women. One should know that domestic violence is a very 
important issue and it needs consideration both at governmental and public level. Newspapers are the major source of information about domestic violence against women.

Table

Violence against Women in Pakistan

\begin{tabular}{|l|c|c|c|c|}
\hline Types of Violence & January-April & May-August & September-December & Total \\
\hline Murder & 27 & 30 & 36 & 93 \\
\hline Rape by force & 19 & 06 & 00 & 25 \\
\hline Burning from Acid & 03 & 00 & 00 & 03 \\
\hline Domestic Violence & 14 & 03 & 09 & 26 \\
\hline Kidnapping & 20 & 26 & 14 & 60 \\
\hline Burning from fire & 03 & 03 & 09 & 15 \\
\hline Karo Kari & 15 & 02 & 12 & 29 \\
\hline Forced marriages & 05 & 04 & 05 & 14 \\
\hline Trafficking & 07 & 00 & 02 & 09 \\
\hline Seizing rights & 01 & 00 & 00 & 01 \\
\hline Suicide & 00 & 00 & 12 & 12 \\
\hline Grand Total & \multicolumn{4}{|l}{} \\
\hline Sor Reras
\end{tabular}

Source: Reports of B.S 2nd Year Students of Social Work Department, University of Karachi.

Many norms and traditions have created misconceptions about women's worth and status in our society. Many factors were involved in it, the desire to dominate and feeling of supremacy, consider women as their personal property, egoism provoked males to violate women's rights.

The increasing incidents of throwing acid and burn women indicate many things, if read the news in detail than the problems of less dowry, poverty, revenge, low income resources and anger were the major causes which formed different shapes of domestic violence. Karokari and killing women in the name of respect have increased the value and admiration of male in the tribe and society. This mania does not end here. This also creates hype in the public when news about these incidents was published in the newspapers.

This table clearly indicates the suffering of Pakistani women. The tragedy is all the more deplorable because Pakistan ratified the Convention on the Elimination of All Forms of Discrimination against Women (CEDAW) on 12 March 1996. The situation of women has not improved much and in some cases we seem to be moving towards worst. Equally deplorable is the fact that though the Huqooq-e-Niswan Bill was passed and implemented in 2006 , it failed to provide protection to women in private sphere because there was no article for women protection in the Bill addressing the issue of domestic violence against women. Though recently passed bill against domestic violence against women and children 2009 is providing full protection to women and children from the harms and pain of violence but the role of law enforcement agencies and judicial system is also important 
to reduce the ratio of domestic violence. It is also essential to make women aware about their rights there fore it could be possible to end this menace in society.

\section{End Notes}

${ }^{1}$ Hayat.A.A.(2002) Women Victims of Social Evils, Pakistan Institute of Security Management, Karachi, Pakistan.

${ }^{2}$ Qureshi.U.M.(2007) Women and Crime ,SBS Publishers and Distributors Pvt. Ltd. New Delhi.

${ }^{3}$ Roznama Jang $20^{\text {th }}$ August 2008

${ }^{4}$ Roznama Aman monthly $1^{\text {st }}$ March, 2004

${ }^{5}$ en.wikipedia.org/wiki/Domestic_Violence Retrieved on $13^{\text {th }}$ July 2009

${ }^{6}$ Alam, Shumaila, Ghayrat Kay Naam Par Qatal Kab Tak in Jang Mid Week Magazine, $25^{\text {th }}$ August 2004, pg.20.

${ }^{7}$ Asghar Raja, NA Bill Out Laws Domestic Violence, Wednesday, August 5, 2009, Dawn

\section{References}

Akanda, Latifa\& Shamim, Ishrat (1985) Women and Violence: A Comparative Study of Rural and Urban Violence against Women in Bangladesh, Women for Women : A Research and Study Group,Dhaka, Bangladesh .

Bahl, Manish(2007) Violence on Women by Men, Cyber Tech Publications, New Delhi, India.

Boyles, William \& Myres Sara (1990) A Guide for Educators Domestic Violence: The Effects on Children, Benerjee Associates, New Jersey, USA.

Hayat.A.A.(2002) Women Victims of Social Evils, Pakistan Institute of Security Management, Karachi, Pakistan.

Lockton, Deborah (1997) Domestic Violence, Cavendish Publishing Limited, London.

Qureshi.U.M.(2007) Women and crime,SBS Publishers and Distributors Pvt. Ltd. New Delhi. 
Prof. Dr. Nasreen Aslam Shah Director, Centre of Excellence for Women's Studies, University of Karachi.

Syed Faisal Hashmi Research Officer, Centre of Excellence for Women's Studies, Universiy of Karach. 